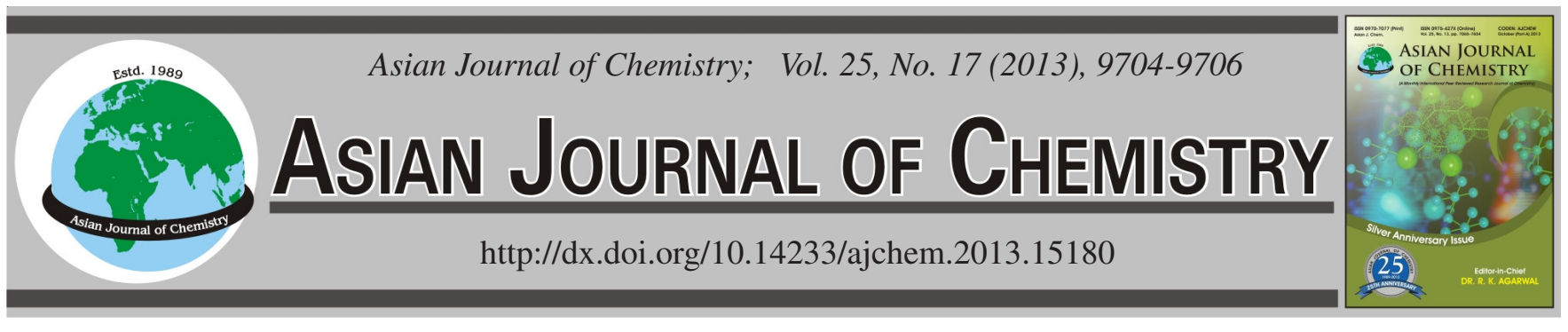

\title{
Assessment of Potential Toxicological Risk for Public Health of Heavy Metals in Wheat Crop Irrigated with Wastewater: A Case Study in Sargodha, Pakistan
}

\author{
Zafar Iqbal Khan ${ }^{1, *}$, Kafeel Ahmad ${ }^{1}$, Muhammad AshraF², Nudrat Aisha Akram ${ }^{3}$, \\ Yasir Rizwan ${ }^{1}$, MuneEba ShaheEn ${ }^{1}$ and Fahim Arshad ${ }^{4}$
}

${ }^{1}$ Department of Biological Sciences, University of Sargodha, Sargodha, Pakistan
${ }^{2}$ University College of Agriculture, University of Sargodha, Sargodha, Pakistan
${ }^{3}$ Department of Botany, GC University, Faisalabad, Pakistan
${ }^{4}$ Department of Botany, University of Education, Okara Campus, Okara, Pakistan

*Corresponding author: E-mail: zikhan11@gmail.com

(Received: 21 January 2013; Accepted: 16 October 2013)

AJC-14258

\begin{abstract}
In the present study, the concentrations of mineral elements in wheat (Triticum aestivum L.) plants was determined to observe the level of elemental pollution in Sargodha, Punjab, Pakistan as well as the abilities of the wheat plants to accumulate heavy metals from the soil supplied with sewage water. An experiment was conducted to study the transfer of heavy metals to the grains of wheat cv. Milate-2011 grown in soil without sewage-sludge treatment (control) and soil supplied with sewage-sludge. A number of heavy metals in soil and wheat grains were analyzed and results showed that $\mathrm{Cr}(5.63-6.21 \mathrm{mg} / \mathrm{kg}), \mathrm{Pb}(5.54-7.08 \mathrm{mg} / \mathrm{kg}), \mathrm{Cu}(12.25-13.64 \mathrm{mg} / \mathrm{kg}), \mathrm{Zn}(31.85-$ $36.4 \mathrm{mg} / \mathrm{kg}), \mathrm{Mn}(31.58-32.67 \mathrm{mg} / \mathrm{kg})$ and $\mathrm{Ni}(3.43-4.32 \mathrm{mg} / \mathrm{kg})$ were found in canal and sewage water irrigated wheat grains, respectively and were much higher than the toxic limit showing a severe risk of health. The Fe level $(25.06-27.11 \mathrm{mg} / \mathrm{kg})$ was below the toxic level, while $\mathrm{Cd}(0.02-0.03 \mathrm{mg} / \mathrm{kg}$ ) level exceeded the maximum tolerable limit particularly for children i.e., $0.002-0.025 \mathrm{mg} / \mathrm{kg}$. While soil Cr (24-36 mg/kg), Pb (80.21-94.84 mg/kg), Cu (23.4-28 mg/kg), Zn (65.2-72.8 mg/kg), Mn (62.8-73.2 mg/kg), Ni (23.4-25.5 mg/kg) and $\mathrm{Fe}(80.21-94.84 \mathrm{mg} / \mathrm{kg}$ ) were found in canal and sewage water treated soil, respectively during this investigation and soil $\mathrm{Cr}, \mathrm{Cu}, \mathrm{Ni}$ and $\mathrm{Zn}$ levels were below the maximum permissible limits for soil, while the reverse was true for other metals. A significant correlation was found between the concentrations of metals in soil as well as their accumulation in grains except Fe concentration. The bio-concentration factor of these heavy metals was higher in wheat grains, so domestic sewage water may lead to heavy metal toxicity in humans if used unprocessed for irrigation purpose.
\end{abstract}

Key Words: Heavy metals, Sewage water, Wheat, Maximum tolerable limits.

ᄂ - - - - - - - - - - - - - - - - - - - - - - - - - - - -

\section{INTRODUCTION}

The protection of food is a serious problem for people globally ${ }^{1}$. Sewage water has gained importance in agriculture due to recycling of nutrients, despite this it contains unreliable quantity of potentially injurious matter that may cause severe diseases $^{2}$. Compounds present in wastewater affect the hydrological properties of soil ${ }^{2,3}$. Heavy metal contamination has been amplified many-fold due to industrial revolution. Different diseases of humans are linked either with mineral shortage or with heavy metals toxicity ${ }^{2,4}$.

Malnutrition also results in increased level of copper and it accumulates in liver resulting in decreased blood hemoglobin concentration and packed cell volume ${ }^{5}$. Iron functions as an important constituent of hemoglobin in the transport of oxygen. Deficiency of Fe may influence brain functioning by altering many metabolic processes that include haemosiderosis and haemochromatosis (bronze pigmentation of the skin) which are caused by extreme buildup of $\mathrm{Fe}$ in the vital organs. Manganese is an important cofactor for several enzymes ${ }^{6}$ and is indefinite in humans. Adverse influences have also been reported on central nervous system due to Mn over exposure ${ }^{7}$. Zinc occurs in all living cells and it is distributed widely in animal and plant tissues. It acts as a cofactor and is a part of numerous enzymes ${ }^{8}$. Toxicity disorders of zinc in human beings comprise vomiting, gastrointestinal irritation, a decrease in high density lipoprotein (HDL) cholesterol and a decreased immune function. Nickel is a necessary constituent in animals ${ }^{9}$. One of the important environmental and industrial pollutants is lead. As suggested by different studies that declining reproductive health and ecological pollutants like lead have a close relationship ${ }^{10}$, while today a serious public health problem is the human exposure to lead ${ }^{11}$. In ruminants, $\mathrm{Pb}$ causes noxious consequences $^{12}$. The objective of the present study was to investigate the effect of domestic sewage water being used for 
wheat irrigation in Sargodha region, Pakistan. Determination of the metal load in wheat plants due to sewage water application would be helpful for assessing the possible threats of heavy metals in human beings consuming grains of such wheat plants.

\section{EXPERIMENTAL}

To determine the effect of sewage water on heavy metals accumulation in wheat (Triticum aestivum L.) plants, a study based on a pot experiment was conducted in the Botanical Garden of the University of Sargodha, Sargodha. The experimental design used in the present study was randomized complete block design (RCBD) with five replications. The seeds of wheat cv. Millat-2011 were sown at the end of November, 2011 and harvested at the end of April, 2012. Airdried soil $(2.5 \mathrm{~kg})$ was sieved through a $4 \mathrm{~mm}$ sieve and then placed in each pot $(15 \mathrm{~cm}$ high and $20 \mathrm{~cm}$ in diameter). The experiment had five replications being each pot as one replicate. The pots were treated with domestic sewage water. Five pots treated with canal water which acted as control. The domestic sewage water was taken from the sewage water pump located at Faisalabad road, $1.5 \mathrm{~km}$ from the University of Sargodha, Sargodha, Pakistan.

Sample collection and preparation: The seed samples from each pot were collected after harvesting. Soil samples were taken from the upper $5 \mathrm{~cm}$ of the soil profile and three random samples of soils were taken from each pot and bulked together to make one composite sample. The samples after drying in air were placed in an oven at $65^{\circ} \mathrm{C}$ for 4 days. The grains/plant were separated from the spikes and ground in a domestic grinder. After 4 days, soil and wheat grain samples were removed from the oven and digested following the wet digestion method of Wolf ${ }^{13}$.

Ultra pure water obtained from Q system (Millipore, MA, USA) was used throughout the research work. Sulfuric acid, hydrogen peroxide and hydrochloric acid of analytical grade (Merck, Germany) were used.

Digestion: Dried samples (each $0.5 \mathrm{~g}$ ) were digested with $\mathrm{H}_{2} \mathrm{SO}_{4}$ and of $\mathrm{H}_{2} \mathrm{O}_{2}$ (1:2) in small conical flasks by placing the digesting material in a digestion chamber. When fumes stopped to evaporate, the samples from the digestion chamber were removed and two $\mathrm{mL}$ of $\mathrm{H}_{2} \mathrm{O}_{2}$ were added to each flask and heated them again. The process was continued until the samples became colourless. The digested material was removed from the digestion chamber and diluted with distilled water to maintain $50 \mathrm{~mL}$ as final volume using a measuring flask. All samples were filtered through Whatmann filter paper.

Metals concentration: Concentrations of $\mathrm{Cu}, \mathrm{Fe}, \mathrm{Mn}$, $\mathrm{Ni}, \mathrm{Cr}, \mathrm{Pb}, \mathrm{Cd}$ and $\mathrm{Zn}$ in the digested samples were determined using an Atomic Absorption Spectrophotometer (AAS). A calibration curve for different metals was constructed by preparing several concentrations of metals from a standard stock solution of $1,000 \mathrm{mg} \mathrm{L}^{-1}$.
Quality control: Precision and accuracy of analyses were assured through repeated analyses of samples against the National Institute of Standard and Technology, Standard Reference Material (SRM 1570) for all the heavy metals. The results were found within $\pm 2 \%$ of the certified value. Quality control measures were taken to assess the contamination and reliability of the data.

Statistical analysis: Data for different attributes were subjected to a statistical analysis using the SPSS software and one-way analysis of variance and correlations worked-out following Steel and Torrie ${ }^{14}$.

Transfer factor: Transfer factor (TF) is one of the key components of animal exposure to metals through food chain. transfer factor was worked out for metals to quantify the relative differences in bio-availability of metals to plants or animals and to identity the efficiency of plant and animal species to accumulate the given metal. Bio-concentration factor is the transfer of a metal from growing medium to plant, which was calculated using the following formula:

$$
\text { Transfer factor }=\frac{\text { Metal concentration in soil }}{\text { Metal concentration in wheat grains }}
$$

\section{RESULTS AND DISCUSSION}

Analysis of variance of data for concentrations of different heavy metals in the soil showed no significant effect $(p<0.05)$ of water treatment on all soil metals except $\mathrm{Cu}$ and $\mathrm{Zn}$ under canal water treatment and $\mathrm{Cr}$ in soil receiving sewage water treatment. In grains, sewage water treatment significantly affected $(p<0.01)$ concentrations of all heavy metals except that of $\mathrm{Cd}$ under both canal water or sewage water treatments. The mean concentrations of $\mathrm{Cr}, \mathrm{Ni}, \mathrm{Pb}, \mathrm{Mn}, \mathrm{Cu}$ and $\mathrm{Zn}$ in wheat plants harvested from soil exposed to wastewater were found to be above the recommended safe values for human beings (Tables 1 and 2).

Transfer factor of metals from the root growing media to plants were calculated on the basis of these results, individual transfer factor of the total metals in agricultural soil and sewage water treated (SWT) samples to wheat grain defined as the ratio between the concentration of heavy metals in the soil and wheat grains. Transfer factor for some metals from soil to grains of wheat crop irrigated with canal water was higher as compared to wheat crop treated with sewage water and the reverse was true for the other metals. The transfer factors between soil and grain for heavy metals were significantly higher under sewage water treatment than under canal water treatment (Table-3).

Under control water treatment, correlations for soil and grain $\mathrm{Mn}, \mathrm{Cu}, \mathrm{Cd}$ and $\mathrm{Cr}$ were found to be significant but negative revealing a strong relationship. While for $\mathrm{Fe}, \mathrm{Pb}$ and $\mathrm{Zn}$ the correlation was non-significant between soil and grains, indicating a weak relationship between them. This indicated

TABLE-1

MEAN DATA OF DIFFERENT HEAVY METALS CONCENTRATION (mg/kg) IN SOIL AFTER CANAL AND SEWAGE WATER TREATMENTS

\begin{tabular}{|c|c|c|c|c|c|c|c|c|}
\hline Treatment & $\mathrm{Cu}$ & $\mathrm{Zn}$ & $\mathrm{Mn}$ & $\mathrm{Pb}$ & $\mathrm{Cd}$ & $\mathrm{Ni}$ & $\mathrm{Fe}$ & $\mathrm{Cr}$ \\
\hline Canal water & 23.4 & 65.2 & 62.8 & 17.84 & 2.93 & 23.4 & 80.21 & 24 \\
\hline Sewage water & 28 & 72.8 & 73.2 & 18.94 & 3 & 25.5 & 94.84 & 36 \\
\hline MPL (Maximum permissible limit) & 50 & 50 & 5 & 13 & 3 & 50 & Nil & 54 \\
\hline
\end{tabular}


TABLE-2

MEAN DATA OF HEAVY METALS CONCENTRATION (mg/kg) IN WHEAT GRAINS AFTER CANAL AND SEWAGE WATER TREATMENTS

\begin{tabular}{|c|c|c|c|c|c|c|c|c|}
\hline Treatment & $\mathrm{Cu}$ & $\mathrm{Zn}$ & $\mathrm{Mn}$ & $\mathrm{Pb}$ & $\mathrm{Cd}$ & $\mathrm{Ni}$ & $\mathrm{Fe}$ & $\mathrm{Cr}$ \\
\hline Canal water & 12.25 & 31.85 & 31.62 & 5.54 & 0.02 & 3.43 & 25.06 & 5.63 \\
\hline Sewage water & 13.64 & 36.40 & 32.67 & 7.08 & 0.03 & 4.32 & 27.11 & 6.21 \\
\hline MPL & 5 & 30 & 10 & 3 & 0.5 & 2 & 100 & 0.03 \\
\hline
\end{tabular}

TABLE-3

TRANSFER FACTORS FOR HEAVY METALS BETWEEN THE SOIL-WHEAT GRAINS UNDER CANAL AND SEWAGE WATER TREATMENTS

\begin{tabular}{ccc}
\hline \multirow{2}{*}{ Metal } & \multicolumn{2}{c}{ Soil-grains } \\
\cline { 2 - 3 } & Canal water treatment & Sewage water treatment \\
\hline $\mathrm{Cu}$ & 0.520 & 0.48 \\
$\mathrm{Zn}$ & 0.480 & 0.44 \\
$\mathrm{Mn}$ & 0.500 & 0.44 \\
$\mathrm{~Pb}$ & 0.310 & 0.34 \\
$\mathrm{Cd}$ & 0.007 & 0.01 \\
$\mathrm{Ni}$ & 0.140 & 0.16 \\
$\mathrm{Fe}$ & 0.310 & 0.28 \\
$\mathrm{Cr}$ & 0.230 & 0.17 \\
\hline
\end{tabular}

an imbalance of iron between the soil and grains. In case of sewage water treatment, correlation of $\mathrm{Zn}, \mathrm{Cr}, \mathrm{Fe}, \mathrm{Cd}$ and $\mathrm{Cu}$ between the soil and grains showed no significant values indicating an imbalance flow of $\mathrm{Cu}$ between soil and grains except $\mathrm{Pb}$ (Table-4).

\begin{tabular}{ccc} 
TABLE-4 \\
\multicolumn{3}{c}{ CORRELATION BETWEEN HEAVY METALS } \\
CONCENTRATION IN THE SOIL AND WHEAT GRAINS \\
UNDER CANAL AND SEWAGE WATER TREATMENTS \\
\hline \multirow{2}{*}{ Metal } & \multicolumn{2}{c}{ Soil-grains } \\
\cline { 2 - 3 } & CWT & SWT \\
\hline $\mathrm{Cu}$ & -0.069 & -0.208 \\
$\mathrm{Zn}$ & 0.327 & 0.134 \\
$\mathrm{Mn}$ & -0.242 & 0.234 \\
$\mathrm{~Pb}$ & -0.041 & 0.050 \\
$\mathrm{Cd}$ & 0.148 & -0.105 \\
$\mathrm{Ni}$ & -0.128 & 0.353 \\
$\mathrm{Fe}$ & -0.002 & -0.413 \\
$\mathrm{Cr}$ & -0.060 & 0.211 \\
\hline$* * *=$ significant at 0.05 and 0.01 levels (2-tailed).
\end{tabular}

The excess usage of wastewater for wheat crop can increase the concentrations of heavy metals in human body. The observed values for $\mathrm{Pb}, \mathrm{Mn}, \mathrm{Cu}, \mathrm{Zn}, \mathrm{Ni}$ and $\mathrm{Cr}$ were higher than the highest respective permissible values except $\mathrm{Cd}$ and $\mathrm{Fe}$. The concentrations of different metals $(\mathrm{Pb}, \mathrm{Ni}, \mathrm{Cu}, \mathrm{Zn}$, $\mathrm{Mn}$ and $\mathrm{Cr}$ ) in various parts of wheat plants was observed by Al-Othman et al. ${ }^{15}$. They investigated the effects of wastewater on heavy metals in wheat and found very low amount of metal elements in grains ${ }^{16}$. They indicated that treated wastewater caused increase in heavy metals in most plant samples, particularly $\mathrm{Mn}, \mathrm{Zn}$ and $\mathrm{Cu}$. Ataabadi et al. ${ }^{17}$ measured the total and extractable levels of metals in the soil .The study explored that domestic sewage water increases heavy metals concentration in soils. This agreed with the findings of Schmidt ${ }^{18}$ who reported that toxic heavy metals of sewage water are transferred from soil to wheat grains as found in the present investigation (Table-3). This shows the potential health problem for humans consuming such type of wheat grains. As in the present study, all values of heavy metals in the wheat grains exceeded those of permissible limits established by $\mathrm{WHO}^{19}$. The present study showed that $\mathrm{Cu}(0.52)$ had maximum transfer rate while $\mathrm{Cd}(0.01)$ the least under both CWT and SWT. Soetan et al..$^{20}$ reviewed the significance of metals in animals and forages. Some of metals are considered more dangerous when gathered in the bodies of animals. The current investigation provides an extra information on contamination in Pakistan. Therefore, there is a dire need of public awareness about the toxic effects and levels above the permissible limits of metals. Overall, a short-term employment of sewage water for irrigation resulted in an elevated level of heavy metal concentration in the field and transfer to plants prior to transfer to human beings and livestock. The possible risk for public health of urban region and framers to utilize numerous available lands receiving waste water for cultivating cereals including wheat and other vegetables. Thus, there is a need for suitable soil quality monitoring system to avoid possible health hazards due to waste water application on agricultural land. The concentrations of heavy metals in the current investigation was much higher than the maximum permissible limit of human beings that may cause heavy metal toxicity. In order to reduce this toxicity, sewage water must be processed before its use for irrigation purposes.

\section{REFERENCES}

1. Z.I. Khan, M. Ashraf, K. Ahmad and N.A. Akram, Biol. Trace Elem. Res., 142, 143 (2011).

2. M.N. Al-Yemeni, H. Sher, M.A. El-Sheikh and M. Eid, Sci. Res. Essays, 6, 966 (2011)

3. A.J.M. Baker and R.R. Brooks, Biorecovery, 1, 81 (1989).

4. K. Ahmad, Z.I. Khan, M. Ashraf, M. Hussain, M. Ibrahim and E.E. Valeem, Pak. J. Bot., 40, 993 (2008).

5. P.N. Singla, P. Chand, A. Kumar and J.S. Kachhawaha, Indian J. Pediatr. 63, 199 (1996).

6. R.K. Murray, D.K. Granner, P.A. Mayes and V.W. Rodwell, McGrawHill, Health Profession Division, USA, edn. 25 (2000).

7. J.C. Tan, D.L. Burns and H.R. Jones, J. Parenteral Enteral Nutr, 30 , 446 (2006).

8. O.G. Arinola, Pak. J. Nutr., 7, 763 (2008).

9. F.H. Nielsen, Trace Elements Human Health Disease, vol. 2, p. 379 (1976).

10. J.P. Bonde, M. Joffe, P. Apostoli, A. Dale, P. Kiss and M. Spano, J. Occup. Environ. Med., 59, 234 (2002).

11. J.L. Pirkle, R.B. Kaufmann, D.J. Brody, T. Hickman, E.W. Gunter and D.C. Paschal, Environ. Health Perspect., 106, 745 (1998).

12. R.Z. Sokol, W. Saixi, Y. Yu-Jui, Z.S. Frank, G. Elizabeth and E.C. Robert, Environ. Health Perspect., 110, 871 (2002).

13. B. Wolf, Commun. Soil Sci. Plant Anal., 13, 1035 (1982).

14. R.G.D. Steel and J.H. Torrie, McGraw Hill Book Co., Inc., New York (1980).

15. Z.A. Al-Othman, R. Ali, M. Abdulaziz, A. Jawad and A.H. Mohamed, Arabian J. Chem., 40, 2099 (2012).

16. M. Feizi and Z.S. Rastghalam, The 11th International and The 4th National Congress on Recycling of Organic Waste in Agriculture, Isfahan, Iran, 26-27 April 2012.

17. M. Ataabadi, M. Hoodaji and P. Najafi, Afr. J. Biotechnol., 10, 4127 (2011).

18. J.P. Schmidt, J. Environ. Qual., 26, 4 (1997).

19. WHO, Plague Manual, World Health Organization. Geneva, Switzerland, p. 134 (1999)

20. K.O. Soetan, C.O. Olaiya and O.E. Oyewole, Afr. J. Food Sci., 4, 200 (2010). 